\title{
INCIDENCE OF CHICKEN ANEMIA VIRUS IN SHARKIA GOVERNORATE CHICKEN FLOCKS
}

\author{
A.M. HEGAZY ${ }^{*}$; F.M. ABDALLAH ${ }^{* *}$; L.K. ABD-EL SAMIE ${ }^{* * *}$ and A.A. NAZIM ${ }^{* * * *}$ \\ * Prof. at Dept. of Avian \& Rabbit Med., Faculty of Vet. Med., Zagazig University. \\ ** Assistant Prof. at Dept of Virology, Faculty of Vet. Med., Zagazig University. \\ *** Colleague at Vet. Hospital, Faculty of Vet. Med., Zagazig University. \\ ${ }^{* * *}$ PhD. at Dept. of Food Hygiene., Zagazig University, Hospitals. \\ E.mail: asmhegazey@gmail.com
}

\section{ABSTRACT}

Received at: $29 / 4 / 2014$

\begin{abstract}
Chicken anemia virus has a great economic impact on poultry industry all over the world but firstly isolated in Japan, 1979. In this study many suspected chicken flocks with history of weakness, anemia, poor condition and vaccination failure at different localities of Sharkia governorate. The presence of the virus was confirmed by PCR assay where organs sample (bone marrow, thymus, bursa of fabricius, liver and spleen) from different age and breeds of chicken farms reacted positive to DNA primers. Serological screening by ELISA showed that $84.72 \%$ of examined serum samples of chickens were positive. Histopathological lesions of infected flocks reflected lymphocytic depletion and hypoplastic bone marrow. It is clear that the virus is a dangerous threat for chicken industry at Sharkia governorate and there is great need for intervention with immunization programs of breeders against the disease.
\end{abstract}

Key words: Chicken anemia virus (CAV) - PCR - ELISA- Histopathology.

\section{INTRODUCTION}

Chicken anemia virus (CAV) is an economically important pathogen with a world-wide distribution. The virus infections are manifested by either clinical or subclinical signs (Schat and Santen 2008). The clinical disease is mainly noticed in young chicks of 10-14 days of age which usually acquire the infection vertically. Chickens older than 2-3 weeks of age are also susceptible to infection but only develop a subclinical disease evidenced by poor vaccine response, increased severity of other infections and decreased cell mediated immune response (McConnell et al., 1993b, Adair 2000, Markowski and Schat, 2003, Schat and Santen 2008). Outbreak of the disease is characterized by anemia, thymus atrophy, bone marrow aplasia and immunosuppression (Adair, 2000, Yuasa et al., 1987). The immunosuppression effect whether directly by itself as it causes severe depletion of lymphocytes from primary and secondary lymphoid organs (Yuasa et al., 1979, Taniguchi et al., 1982 \& 1983) consequently destruction of erythroblastoid cells in the bone marrow and thymocytes in the thymic cortex of the newly hatched chickens (Kato et al., 1995) or indirectly as it participates other immunosuppressive viruses such as infectious bursal disease virus (IBDV), Marek's disease virus (MDV) or reticuloendotheliosis virus (REV). In dual infections, anemia was produced even when the chickens were inoculated at two or more weeks of age or in chickens with maternal antibody (Yuasa et al., 1980, Bülow et al., 1986a).

The first report of CAV was from contaminated vaccines in Japan (Yuasa et al., 1979). In China, it was first isolated in 1996 (Zhou et al., 1996), Argentina (Craig, 2009), India (Natesan et al., 2006), Nigeria (Ducatez et al., 2005), South Korea (Kim et al., 2010) and other countries have reported outbreaks in commercial flocks. Virus isolates were thought to belong to a single serotype and were antigenically indistinguishable by serum neutralization tests (Yuasa and Imai, 1986).

Detection of CAV using molecular techniques including polymerase chain reaction (PCR) provides an alternative to conventional testing as it is more sensitive and specific (USda. Gov.).

The study aimed to reflect the prevalence of CAV among suspected chicken farms at different localities of Sharkia governorate by using serological survey, histopathological changes and molecular identification. 


\section{MATERIALS and METHODS}

Examined birds: Out of five different localities at Sharkia governorate, Chickens were sourced from 27 farms with complains of high mortalities, poor performance, recurrent infections and vaccination failure.

Samples: Performing postmortem examination of selected birds, 360 blood samples were collected for determination of hematocrit values and serum for ELISA serological assay. Organs (Thymus loops, bone marrow, bursa of Fabricius, liver, and spleen) were collected and stored at $\left(-70^{\circ} \mathrm{C}\right)$ to be used for PCR analyses and hitopathological examination.

Packed cell volume (PCV): was carried out according to (Duncan and Prasse, 1986) as preliminary diagnosis of CAV.

ELISA assay: Commercial chicken anemia virus antibody ELISA kit ProFLOK $^{\circledR}$ PLUS, Symbiotic Corporation, San Diego, CA, USA; Cat. No. 92127800-228-4305) was used under the manufacturer instructions for specific prevalence of the virus.

Histopathological examination: Visceral organs (thymus, bursa of Fabricius, liver, and spleen) were fixed with $10 \%$ buffered neutral formalin solution. Femurs were split longitudinally to expose bone marrow then fixed and decalcificated in 5\% formic acid for 2 weeks. Samples dehydrated, embedded in paraffin and sectioned (4 micron thickness), and stained with hematoxylin and eosin (H\&E) for microscopic examination (Haridy et al., 2012).

PCR identification: Tissues were prepared according to (Zhou et al., 1997) and DNA was extracted by using commercial extraction kits $\left(\right.$ QIAGEN $^{\circledR}$ EZ1 Virus Mini Kit Version 2.0(48), Cat. No. 955134) in automated extractor (QIAGEN ${ }^{\circledR}$ EZ1 (BioRobot), Serial No. 0502f0707) according to manufacturer instructions.

Amplification of DNA was performed in the thermocycler (T3- Thermocycler, Biometra) using:

1- Reddy-Mix ${ }^{\mathrm{TM}}$ PCR Master Mix (THERMO Scientific $^{\circledR}$, Cat. No. AB-0575/LD/A, Lot No. 1404/15)

2- Two primers, CAV A1.1 (5`AAT GAA CGC TCT CCA AGA AG 3') and CAV A1.2 (5` AGC GGA TAG TCA TAG TAG AT 3'), (MWG-Biotech $A G^{\circledR}$, Batch No. 523470 \& 523471 respectively) were used to amplify a 583 base pair (bp) DNA fragment (Tham and Stanislawek, 1992).

3- DNA Ladder of $100 \mathrm{~Pb}$ (QIAGEN ${ }^{\circledR}$, Lot No. 3)
PCR assay was performed in a final volume of $50 \mu \mathrm{l}$ containing $25 \mu$ l Reddy-Mix ${ }^{\mathrm{TM}}$ PCR Master Mix, 18 $\mu 1$ PCR Grade Water, $1 \mu$ of each Primer, and $5 \mu 1$ template.

The amplification was performed under the following conditions: one cycle of initial denaturation step at $95^{\circ} \mathrm{c}$ for $15 \mathrm{~m}$, followed by $30 \mathrm{cycles}$ of $95^{\circ} \mathrm{c}$ for $1 \mathrm{~m}$, $56^{\circ} \mathrm{C}$ for $1 \mathrm{~m}$, and $72^{\circ} \mathrm{C}$ for $1 \mathrm{~m}$ representing denaturation, annealing, and extension steps respectively. Finally, one cycle of final extension step at $72^{\circ} \mathrm{c}$ for $5 \mathrm{~m}$.

The amplified products were analyzed using electrophoresis unit. It was loaded to $2 \%$ agarose, stained by ethidium bromide, visualized under ultraviolet light, and photographed by a gel documentation system using Canon Power-Shot ${ }^{\circledR}$ G10 camera and the data was analyzed using computer software (Sambrook and Russel, 2001).

\section{RESULTS}

\section{Clinical signs and lesions:}

Examined birds showed signs of anemia, generalized weakness, depression, droopy appearance, pale comb and wattles, stunting, growth retardation and high mortality rate. The necropsy findings were watery blood, yellow fatty bone marrow, markedly atrophied thymus glands, atrophied bursa of Fabricius and enlarged liver and spleen. Subcutaneous and intramuscular hemorrhages were reported in some cases and the average PCV was $17 \%-22 \%$ indicating reduced hematocrit value.

\section{ELISA:}

Out of 360 tested serum samples, 305 (84.72\%) showed positive result to CAV specific antibodies, (Table 1).

\section{Histopathology:}

Histopathological examination, of the naturally infected tissues which were positive to CAV DNA by PCR assay, showed marked hypoplasia in bone marrow (Fig. 8) and generalized lymphocytic depletion in thymus (Fig. 7) and spleen (Fig. 5). Bursa of Fabricius showed moderate depletion in lymphoid follicles with presence of perifollicular edema (Fig. 6). Liver showed cellular swelling and apoptosis with marked apoptotic bodies (Fig. 2, 3, 4).

\section{Identification of CAV by PCR:}

Analysis of DNA extracted (thymus, bone marrow, bursa of Fabricius, liver, and spleen) from tissues of diseased chickens by agarose gel electrophoresis yielded positive reactions of correct size as primers (583 base pairs in size), (Fig. 1). 


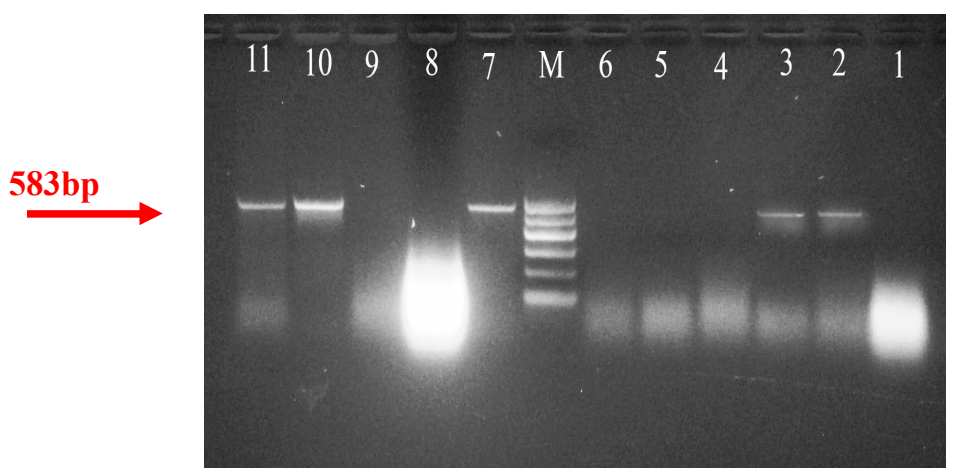

Fig. 1: PCR products (583 bp in size) of amplified CAV-DNA extracted from tissues of examined chickens.

Lanes 2, 3, 10, and 11 are positive

Lanes 4, 5, 6, 8, and 9 are negative

Lanes 1 and 7 are control negative and positive respectively

M: size marker (100 base pairs ladder)
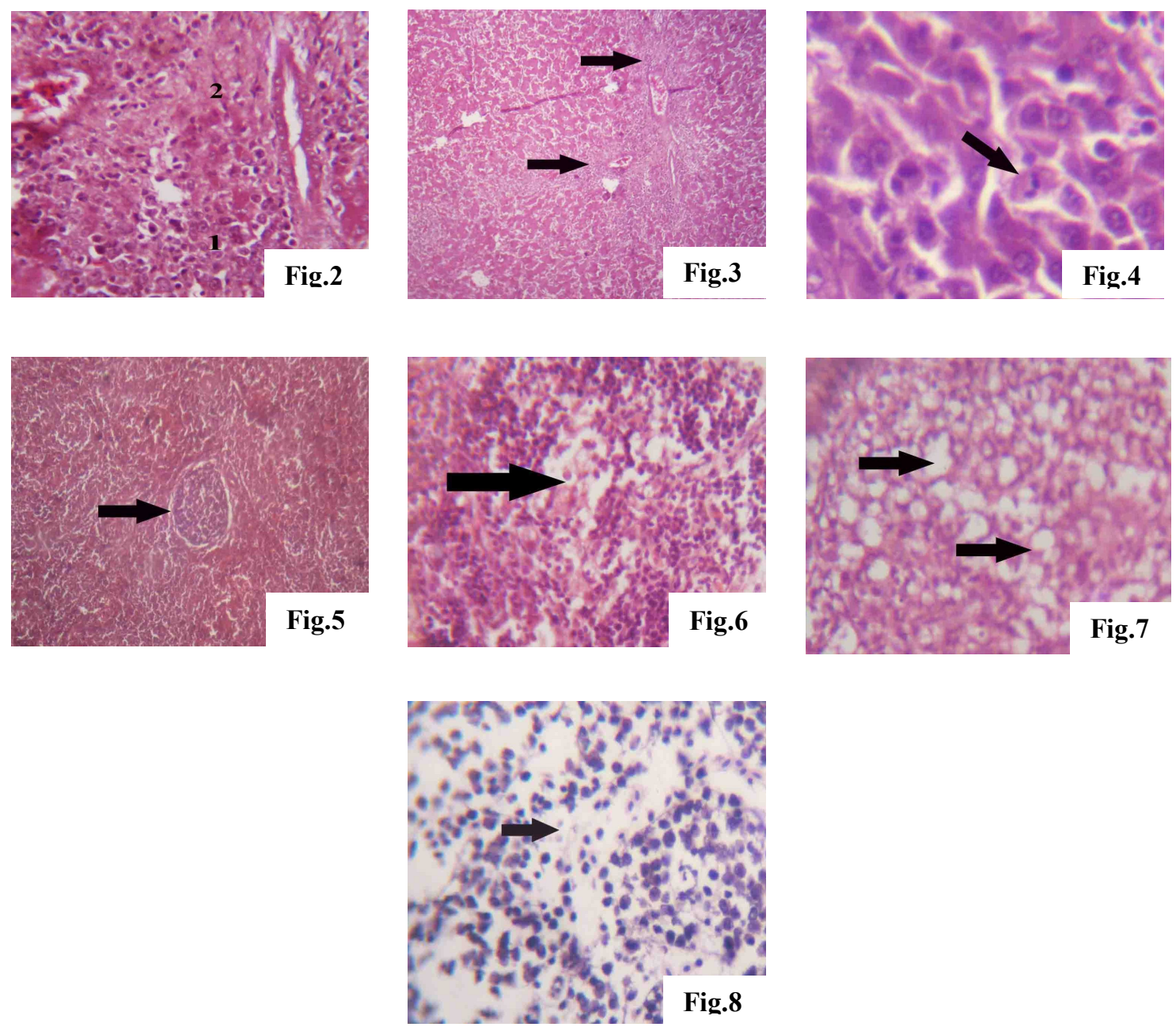

Fig. 2: Liver showing congestion of portal blood vessels with perivascular fibrosis (1) and proliferation of the bile duct (2). H\&E., X 1200.

Fig. 3: Liver showing portal proliferation of fibroblasts aggregation of round cells and (arrows). H\&E., X 300.

Fig. 4: Liver showing hepatocyte apoptosis with marked apoptotic bodies (arrow). H\&E., X 1200.

Fig. 5: Spleen showing depletion of the white pulps (arrow) and disarrangement of the normal architecture. H\&E., X 300.

Fig. 6: Bursa of Fabricius showing moderate depletion of lymphoid follicles (arrows) with presence of perifollicular edema. H\&E., X 1200.

Fig. 7: Thymus showing marked lymphoid depletion (arrows). H\&E., X 1200.

Fig. 8: Bone marrow section showing markedly hypocellular marrow (arrow). H\&E., X 1200. 
Assiut Vet. Med. J. Vol. 60 No. 142 July 2014

Table 1: Results of serological assay (ELISA) for CAV in chicken flocks at Sharkia

\begin{tabular}{|c|c|c|c|c|c|c|}
\hline $\begin{array}{c}\text { Flock } \\
\text { No. }\end{array}$ & Locality & Breed & $\begin{array}{l}\text { No. of } \\
\text { Sample }\end{array}$ & $\begin{array}{l}\text { No. of } \\
\text { Positive }\end{array}$ & $\begin{array}{c}\text { Positive } \\
\%\end{array}$ & $\begin{array}{l}\text { Mean } \\
\text { Titers }\end{array}$ \\
\hline 1 & Al-Husainiah & Bovans & 14 & 12 & 85.71 & 2154.49 \\
\hline 2 & Al-Husainiah & Bovans & 15 & 13 & 86.67 & 2119.31 \\
\hline 3 & Al-Husainiah & Cobb & 5 & 5 & 100 & 2507.09 \\
\hline 4 & Al-Husainiah & Hubbard & 25 & 23 & 92 & 2319.97 \\
\hline 5 & Al-Kenaiat & Bovans & 17 & 14 & 82.35 & 2115.58 \\
\hline 6 & Belbeis & Lohmann & 16 & 13 & 81.25 & 2053.73 \\
\hline 7 & Belbeis & Hy-Line & 12 & 12 & 100.00 & 2305.3 \\
\hline 8 & Belbeis & Hubbard & 12 & 12 & 100 & 2552.03 \\
\hline 9 & Belbeis & Hisex & 18 & 15 & 83.33 & 2038.91 \\
\hline 10 & Belbeis & Saso & 19 & 18 & 94.74 & 2536.56 \\
\hline 11 & Belbeis & Cobb & 16 & 13 & 81.25 & 2560.70 \\
\hline 12 & Hehya & Saso & 25 & 22 & 88 & 2525.03 \\
\hline 13 & Hehya & Cobb & 10 & 10 & 100 & 2521.46 \\
\hline 14 & Kafr Sakr & Cobb & 20 & 18 & 90 & 2236.17 \\
\hline 15 & Kafr Sakr & Hisex & 10 & 7 & 70.00 & 2067.29 \\
\hline 16 & Kafr Sakr & Hisex & 10 & 9 & 90.00 & 2009.54 \\
\hline 17 & Kafr Sakr & Hubbard & 10 & 8 & 80 & 2119.26 \\
\hline 18 & Kafr Sakr & Hy-Line & 18 & 12 & 66.67 & 1815.64 \\
\hline 19 & Kafr Sakr & Saso & 10 & 7 & 70 & 1821.04 \\
\hline 20 & Menya El-kamh & Lohmann & 10 & 8 & 80 & 2052.26 \\
\hline 21 & Menya El-kamh & Bovans & 14 & 12 & 85.71 & 2031.29 \\
\hline 22 & Menya El-kamh & Bovans & 6 & 4 & 66.67 & 1582.74 \\
\hline 23 & Menya El-kamh & Bovans & 6 & 5 & 83.33 & 2320.88 \\
\hline 24 & Menya El-kamh & Cobb & 10 & 7 & 70 & 2177.29 \\
\hline 25 & Menya El-kamh & Cobb & 10 & 9 & 90 & 2420.12 \\
\hline 26 & Menya El-kamh & Hy-Line & 14 & 11 & 78.57 & 2062.52 \\
\hline 27 & Menya El-kamh & Saso & 8 & 6 & 75 & 2803.30 \\
\hline Total & & & 360 & 305 & 84.72 & 2222.28 \\
\hline
\end{tabular}

*Age of different flocks ranged from between 3 weeks to 80 weeks 


\section{DISCUSSION}

The investigated chicken flocks showed generalized weakness, depression, droopy appearance, pale comb and wattles, stunting, growth retardation, and high mortalities. The packed cell volumes measured were markedly reduced (average PCV was between 17\% and 22\%). Necropsy findings of the sampled chickens revealed watery blood, yellow fatty bone marrow, markedly atrophied thymus glands, atrophied bursa of Fabricius, and enlarged livers and spleens. The clinical signs, postmortem lesions, and PCV values agreed with the findings of (Yuasa et al., 1979, Taniguchi et al., 1982 \& 1983, Aly 2001) and (Pope 1991, Ramadan et al., 1998) who stated that a case of hematocrit value below $27 \%$ with yellowish changes in bone marrow and thymic atrophy may be indicative to CAV infection beside other means of diagnosis.

The serologic survey performed in this study involved 5 different localities of Sharkia province, Egypt representing different breeds, ages and types of production. Bird's age was intended to exceed the age of 3 weeks to exclude maternally derived immunity that persists for about 3 weeks. The overall findings of the study proved that CAV is widely distributed among chicken flocks where $84.72 \%$ of the tested serum samples reacted positive at different localities of Sharkia governorate, Egypt. (Zaki and El-Sanousi, 1994) reported that in Egypt, the incidence of CAV antibodies in serum samples collected from broiler breeder, layer, and day old broiler flocks was $70 \%$, (Amin et al., 1998) stated that it was 97.4\% among 21 native and foreign grandparent, parent, and broiler flocks in 8 provinces, (Sabry et al., 1998) recorded that 1916 tested serum samples from 118 flocks of different breeds and ages in different governorates showed a high degree of positivity for CAV antibodies in both imported and locally produced broiler parent, broiler, and layer flocks, while (Islam 2003) reported that CAV seroprevalence was $74.6 \%$ and $67.3 \%$ in commercial broiler and broiler breeder flocks respectively in Sharkia province. In other countries, CAV serological findings was $85.7 \%$ in commercial layer flocks in Turkey (Kuyucuoglu et al., 2003), 86\% in commercial broiler flocks in Nigeria (Owoade et al., 2004), 67.3\% in commercial layer flocks in Khartoum state, Sudan (Ballal et al., 2005), $87.7 \%$ in commercial broiler flocks in Iran (Mahzounieh et al., 2005), 82.61\% in commercial broiler flocks in Northern Jordan (Dergham 2006) and $(96.15 \%)$ in unvaccinated commercial broiler chicken farms in Malaysia (Hailemariam et al., 2008).

Detection of CAV antibodies in tested flock's sera indicates either vertical/horizontal infection or passive acquired immunity from breeders via yolk. Passively acquired immunity was excluded depending on age factor where sera were collected after 3 weeks of age, at which maternal antibodies decayed as mentioned by (McNulty et al., 1988). The presence of CAV antibodies in tested flock's sera with no history of clinical signs, lesions or vaccination certainly indicates horizontal infection through direct and indirect contact with virus-contaminated dust, water or feed with feces (Rosenberger 1991) specially that the virus shows extreme physical and chemical resistance to inactivation and so persists for long period in poultry houses (Yuasa 1992).

Histopathological examination go with the findings of (Sakr and Talaat, 1991) who observed marked depletion of the lymphocytes in the thymus and bursa of Fabricius beside severe hypoplasia in hematopoietic cells in bone marrow. In addition, (Hussein et al., 2002) reported some bursal changes with various degrees of atrophy in the lymphoid follicles with scattered necrotic foci, which were probably attributed to secondary infections. These findings similar to (Goryo et al., 1987, Smyth et al., 1993) that proved immunosuppressive effect of the virus may be attributed directly to its destructive effect of hematopoietic and lymphopoietic tissues leading to impaired immune response. Moreover (Adair et al., 1991) stated that CAV infection causes severe defects in splenic T-lymphocyte functions in form of decreased responsiveness to phytohemagglutinin, concanavalin $\mathrm{A}$ and fall in interleukin production. Macrophage concentration and functions are also severely reduced after in vivo or in vitro exposure to the virus such as interleukin-1 (IL-1) production, $\mathrm{Fc}$ receptor expression, phagocytosis and bactericidal activity (Cloud et al., 1992; McConnell et al., 1993a \& b). The adverse effects of the virus on lymphocyte and macrophage functions have substantial negative effects on immune response leading to enhancement of the concurrent infection with other pathogens and vaccination failure (Adair, 2000). On the other hand (Goryo et al., 1989, Smyth et al., 1993) reported that bursa of Fabricius was not susceptible to CAV infection and (Haridy et al., 2012) stated that there were no prominent or remarkable lesions in bone marrow and appeared fatty with no inclusions in hematopoitic cells of SPF chickens experimentally infected at 4 weeks old with CAV.

PCR assay is proved to be specific and definitely more sensitive than cell culture isolation of the virus, especially that DNA can be extracted from the same tissues as used for virus isolation (Miller et al., 2001; Soiné et al., 1993; Drén et al., 1994). In this study, PCR yielded positive reactions with correct size as primers (583 bp) for confirmation of CAV infection in chicken flocks that showed clinical signs, reduced hematocrit value and postmortem lesions. Similar result was reported by (Tham and Stanislawek, 1992). In all PCR positive flocks, the thymus and bone 
marrow samples were positive, this is probably because CAV targets erythroid and lymphoid progenitor cells in the bone marrow and thymus respectively (Adair, 2000). While (Hailemariam et al., 2008) recorded that out of 60 commercial broiler breeder hens tested for the presence of CAV DNA by nested PCR assay, the highest percentage of positive samples was detected in spleen where 45 samples out of $60(75 \%)$ were positive. Duodenum was found to be an organ with the least distribution of CAV DNA in which 28 organs out of $60(46.7 \%)$ were positive. There is no statistical significant $(\mathrm{P}<0.05)$ difference in the percentages of CAV DNA between spleen, bone marrow, thymus and ovary. However, the distributions of viral DNA in liver, duodenum and oviduct were significantly less $(\mathrm{P}<0.05)$ from the rest of the organs.

It is confirmed that CAV is widely distributed among chicken flocks in Sharkia governorate, Egypt by using PCR. Moreover, ELISA is a sensitive test for detection of clinical and subclinical forms of the virus infection. The virus has immunosuppressive effect due to destruction of lymphoid organs consequently causes huge economic losses. Adoption of breeder immunization programs against CAV is an urgent demand to avoid vertical transmission of the virus and protect the progeny via maternal antibodies.

\section{REFERENCES}

Adair, B.M. (2000): Immunopathogenesis of chicken anemia virus infection. Develop. Comp. Immunol., 24: 247-255.

Adair, B.M.; McNeilly, F.; McConnell, C.D.G.; Todd, D.; Nelson, R.T. and McNulty, M.S. (1991): Effects of chicken anemia agent on lymphokine production and lymphocyte transformation in experimentally infected chickens. Avian Dis., 35: 783-792.

Aly, Mona M. (2001): Isolation of chicken infectious anemia virus from outbreaks in broilers chickens in Egypt. J. Egypt Vet. Med. Ass., 61(6): 137-147.

Amin, A.A.; Hassan, M.K.; Aly, M.M. and AbdelZaher, A. (1998): A serological study of the prevalence of chicken infectious anemia in commercial flocks. Proc. of the $5^{\text {th }}$ Sci. Conf., Egypt. Vet. Poult. Assoc., P: 69-75.

Ballal, A.; Elhussein, A.M. and Abdelrahim, I.S.A. (2005): Serological survey of chicken infectious anemia virus in commercial chicken flocks in Khartoum State-Sudan. J. of Anim. and Vet. Advances, 4(7): 666-667.

Bülow, V.V.; Rudolph, R. and Fuchs, B. (1986a): Enhanced pathogenicity of chicken anemia agent (CAA) in dual infection with Marek's disease virus (MDV) and infectious bursal disease virus (IBDV) or Reticuloendotheliosis virus (REV). J. Vet. Med. B, 33: 93-116.
Cloud, S.S.; Rosenberger, J.K. and Lillehoj, H.S. (1992): Immune dysfunction following infection with chicken anemia agent and infectious bursal disease virus. 2. Alterations of in vitro lymphoproliferation and in vivo immune responses. Vet. Immunol. Immunopathol., 34: 353-366.

Craig, M.I. (2009): Molecular Characterization of Chicken Infectious Anemia Virus Circulating in Argentina During 2007. Avian Dis. 53, 331-335.

Dergham, Roussan A. (2006): Serological survey on the prevalence of chicken infectious anemia virus in commercial broiler chicken flocks in northern Jordan. Int. J. of Poult. Sci., (6): 544-546.

Drén, C.N.; Koch, G.; Kant, A.; Verschueren, C.A.J.; Bvan der Eb, A.J. and Noteborn, M.H.M. (1994): A hot start PCR for the laboratory diagnosis of CAV. Proc. Int. Symp. Infect. Bursal Dis. Chick. Infect. Anemia, Rauischholzhausen, Germany, 16-20 June. P: 413-420.

Ducatez, M.F.; Owoade, A.A.; Abiola, J.O. and Muller, C.P. (2005): Molecular epidemiology of chicken anemia virus in Nigeria. Arch Virol. 151: 97-111

Duncan, J.R. and Prasse, K.W. (1986): Veterinary medicine laboratory clinical pathology, $2^{\text {nd }}$ edition, $\mathrm{CH}$ : 1 Erythrocytes. Iowa state university press. Ames, Iowa, P 7-9.

Goryo, M.; Suwa, T.; Matsumoto, S.; Umemura, T. and Itakura, C. (1987): Serial propagation and purification of chicken anemia agent in MDCC- MSB1 cell line. Avian Pathol., 16: 149-163.

Goryo, M.; Suwa, T.; Umemura, T.; Itakura, C. and Yamashiro, S. (1989): Histopathology of chicks inoculated with chicken anaemia agent (MSB1-TK5803 strain). Avian Pathol., 18: 73-89.

Hailemariam Zerihun; Abdul Rahman Omar; Mohd Hair-Bejo and Tan Ching Giap (2008): Detection and characterization of chicken anemia virus from commercial broiler breeder chickens. Virology J., 5: 128

Haridy, M.; Sasaki, J.; Ikesawa, M.; Okada, K. and Goryo, M. (2012): Pathological and immunohistochemical studies of subclinical infection of chicken anemia virus in 4-weeksold chickens. J. Vet. Med. Sci., 74 (6): 757-764.

Hussein, H.A.; Sabry, M.Z.; El-Ebiary, E.A.; El-Safty, M. and Abdel-Hady, A.L. (2002): Chicken infectious anemia virus in Egypt: Molecular diagnosis by PCR and isolation of the virus from infected flocks. Ar. J. Biotech., 5(2): 263-274.

Islam, T.M.M. (2003): Serological studies on chicken infectious anemia virus in Sharkia governorate. 
M. V. Sc. Thesis, Zagazig University, Faculty of Veterinary Medicine.

Kato, A.; Fujino, M.; Nakamura, T.; Ishihama, A. and Otaki, Y. (1995): Gene organization of chicken anemia virus. Virology, 209: 480-488.

Kim, H.R.; Kwon, Y.K.; Bae, Y.C.; Oem, J.K. and Lee, O.S. (2010): Molecular characterization of chicken infectious anemia viruses detected from breeder and broiler chickens in South Korea. Poult Sci. 89: 2426-2431.

Kuyucuoglu, Y.; Hadimli, H.H.; Kenar, B. and Ucan, U.S. (2003): Detection of chicken infectious anemia virus antibody in layer operations by using ELISA in Afyon region. Vet. Hek. Mikrobiyol. Derg., 3: 21-26.

Mahzounieh, M.; Karimi, I. and Zahraei Salehi, T. (2005): Serologic evidence of chicken infectious anemia in commercial chicken flocks in Shahrekord, Iran. Int. J. of Poult. Sci., 4 (7): 500-503.

Markowski-Grimsrud, C.J. and Schat, K.A. (2003): Infection with chicken anaemia virus impairs the generation of pathogen-specific cytotoxic $\mathrm{T}$ lymphocytes. Immunology, 109:283-294.

McConnell, C.D.G.; Adair, B.M. and McNulty, M.S. (1993a): Effects of chicken anemia virus on macrophage function in chickens. Avian Dis., 37: 358-365.

McConnell, C.D.G.; Adair, B.M. and McNulty, M.S. (1993b): Effects of chicken anemia virus on cell-mediated immune function in chickens exposed to the virus by a natural route. Avian Dis., 37: 366-374.

McNulty, M.S.; Connor, T.J.; McNeilly, F.; Kirkpatrick, K.S. and McFerran, J.B. (1988): A serological survey of domestic poultry in the United Kingdom for antibody to chicken anemia agent. Avian Pathol., 17: 315-324.

Miller, M.; Oswald, W.B.; Scarlet, J. and Schat, K.A. (2001): Patterns of chicken infectious anemia virus (CIAV) seroconversion in three Cornell SPF flocks.Proc.2nd Int. Symp. Infect. Bursal Dis. Chick. Infect. Anemia, Rauischholzhausen, Germany, 410-417.

Natesan, S.; Kataria, J.M.; Dhama, K.; Rahul, S. and Bhardwa, N. (2006): Biological and molecular characterization of chicken anaemia virus isolates of Indian origin. Virus Res. 118, 78-86.

Owoade, A.A.; Oluwayelu, D.O.; Fagbohun, O.A.; Ammerlaan, W.; Mulders, M.N. and Muller, C.P. (2004): Serologic evidence of chicken infectious anemia in commercial chicken flocks in southwest Nigeria. Avian Dis., 48(1): 202-205.

Pope, C.R. (1991): Chicken anemia agent. Vet. Immunol. Immunopathol., 30: 51-65.

Ramadan, G.; El-Hussini, H. and Bekhit, A. (1998): Biochemical and hematological characterization of chicken anemia virus (CAV). Assuit Vet. Med. J., 38(76): 209-222.

Rosenberger, J.K. (1991): IBDV - CAV interaction: results are discussed. Poult. Digest., 50(3): 3637.

Sabry, M.Z.; Khafagy, A.K.; Elsamadony, H.A. and Elmahgoub, K.M. (1998): A seroepidemiological survey of meat- and eggtype chickens in Egypt for antibody to chicken infectious anemia virus. Proc. of the 5th Sci. Conf., Egypt. Vet. Poult. Assoc., P: 77-98.

Sakr, E.A. and Talaat, A.M. (1991): Pathological changes in chicks induced by chicken anemia agent, isolated for the first time in Egypt. Benha Vet. Med. J., 2(1): 106-117.

Sambrook, J.; Russel, D.W. (2001): Molecular Cloning: A Laboratory Manual 3rd Ed. Cold Spring Harbor Laboratory Press. Cold Spring Harbor, NY.

Schat, K.A. and Van Santen, V. (2008): Chicken infectious anemia. In: Diseases of poultry, 12th ed. Y. M. Saif, A.M. Fadly, J.R. Glisson, L.R. McDougald, L.K. Nolan, and D.E. Swayne, eds. Wiley-Blackwell, Ames, IA. pp. 211-235.

Smyth, J.A.; Moffett, D.A.; McNulty, M.S.; Todd, D. and Mackie, D.P. (1993): A sequential histopathologic and immunocytochemical study of chicken anemia virus infection at one day of age. Avian Dis., 37: 324-338.

Soiné, C.; Watson, S.K.; Rybicki, E.; Lucio, B.; Nordgren, R.M.; Parrish, C.R. and Schat, K.A. (1993): Determination of the detection limit of the polymerase chain reaction for chicken infectious anemia virus. Avian Dis., 37: 467-476.

Taniguchi, T.; Yuasa, N.; Maeda, M. and Horiuchi, T. (1982): Hematopathological changes in dead and moribund chicks induced by chicken anemia agent. Natl. Inst. Anim. Health Q., (Jpn) 22: 61-69.

Taniguchi, T.; Yuasa, N.; Maeda, M. and Horiuchi, T. (1983): Chronological observations on hemato-pathological changes in chicks inoculated with chicken anemia agent. Natl. Inst. Anim. Health Q., (Jpn) 23: 1-12.

Tham, K. and Stanislawek, W.L. (1992): Polymerase chain reaction amplification for direct detection of chicken anemia virus DNA in tissues and sera. Avian Dis., 36: 1000-1006.

Yuasa, N. (1992): Effect of chemicals on the infectivity of chicken anaemia virus. Avian Pathol., 21: 315-319.

Yuasa, N. and Imai, K. (1986): Pathogenicity and antigenicity of eleven isolates of chicken anaemia agent (CAA). Avian Pathol. 15: 639-645.

Yuasa, N.; Taniguchi, T. and Yoshida, I. (1979): Isolation and some characteristics of an agentinducing anemia in chicks. Avian Dis., 23: 366-385. 
Yuasa, N.; Taniguchi, T.; Noguchi, T. and Yoshida, I. (1980): Effect of infectious bursal disease virus infection on incidence of anemia by chicken anemia agent. Avian Dis., 24: 202-209.

Yuasa, N.; Imai, K.; Watanabe, K.; Saito, F.; Abe, M. and Komi, K. (1987): Aetiological examination of an outbreak of haemorrhagic syndrome in a broiler flock in Japan. Avian Pathol., 16: 521-526.

Zaki, A.A. and El-Sanousi, A.A. (1994): Chicken anemia agent in Egypt: A serological survey of antibody against chicken anemia agent I some commercial chicken flocks using indirect immunofluorescent technique. Vet. Med. J. Giza, 24(3): 53-58.

Zhou, W.; Yang, B.; Shen, B.; Han, S. and Zhou, J. (1996): A serologic survey of antibody against chicken infectious anemia virus by indirect immunofluorescent assay in domestic poultry in China. Avian Dis. 40, 358-360.

Zhou, W.; Shen, B.; Yang, B.; Han, S.; Wei, L.; Xiao, B. and Zhou, J. (1997): Isolation and identification of chicken infectious anemia virus in China. Avian Dis., 41: 361-364.

\section{تعيين حدوث الأصابة بفيروس الأنيميا فى قطعان الاجاج بمحافظة الثرقية

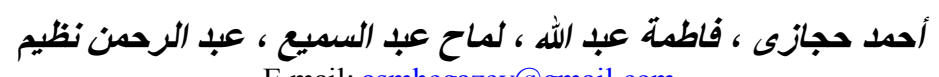 \\ E.mail: asmhegazey@gmail.com}

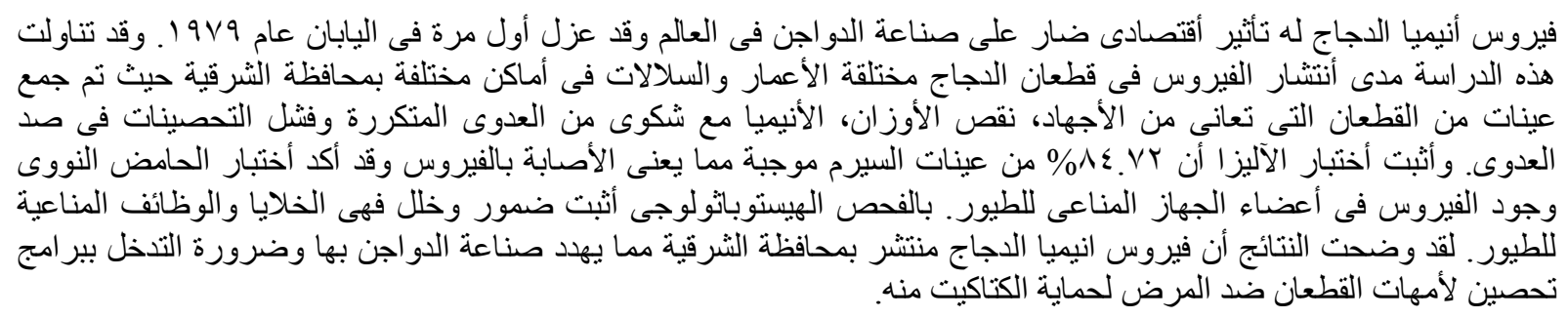

